POLITYKA ENERGETYCZNA - ENERGY POLICY JOURNAL

$2020 \uparrow$ Volume $23 \multimap$ Issue $3 \nrightarrow 93-110$

DOI: $10.33223 / \mathrm{epj} / 127591$

\title{
Ukraine's electricity system striving for European energy integration
}

ABSTRACT: The strategic goals of EU energy development have been clarified, based on efforts to increase and comply with environmental protection requirements, reducing energy consumption in the manufacturing and service sector, reduce dependence on energy imports, and increase the involvement of renewable resources in energy. The structure of the unified energy system of Ukraine was monitored. The volumes of electricity released by various power-generating enterprises in Ukraine, as well as the existing capacity of main and inter-state electric power grids for transmission of electricity, were analyzed. The volume of electricity exports and imports of the unified energy system of Ukraine and its possibilities to increase exports to the EU countries have been diagnosed. It has been proven that due to the change in the operating model of the electricity market the liberalization of the electricity market of Ukraine promotes the attraction of investment resources aimed at branching the possibilities of importing electricity generated in Ukraine into the ENTSO-E system. The

$\triangle$ Corresponding Author: Rostislav Tulchinskiy; e-mail: r_istu@ukr.net

${ }^{1}$ Department of management and public administration, IHE “Academician Yuriy Bugay International Scientific and Technical University”, Ukraine; ORCID iD: 0000-0003-1605-1403; e-mail: r_istu@ukr.net

2 Department of management and civil service, Chernihiv National Technological University, Ukraine; ORCID iD: 0000-0002-8628-9444; e-mail: butko.mykola@ukr.net

3 Economics and entrepreneurship department, National Technical University of Ukraine "Igor Sikorsky Kyiv Polytechnic Institute", Ukraine; ORCID iD: 0000-0002-1409-38481 e-mail: tuha@ukr.net

4 Department of management and public administration, IHE “Academician Yuriy Bugay International Scientific and Technical University”, Ukraine; ORCID iD: 0000-0002-6658-7065; e-mail: khudolei@ukr.net

2020. The Author(s). This is an open-access article distributed under the terms of the Creative Commons Attribution-ShareAlike International License (CC BY-SA 4.0, http://creativecommons.org/licenses/by-sa/4.0/), which permits use, distribution, and reproduction in any medium, provided that the Article is properly cited. 
structural tendencies of changes in generated electricity in final consumption at the expense of renewable energy sources of the European countries and Ukraine were studied. Options for increasing the efficiency of renewable energy sources are proposed The use of renewable energy sources on the basis of leveling out certain disadvantages is proposed. The directions improve the management of electricity enterprises in the conditions of the European integration choice of Ukraine including towards attracting investment resources through the use of public-private partnerships to improve the efficiency of the energy system of Ukraine are substantiated.

KEYWORDS: energy efficiency, generation, electricity, European integration processes; renewable energy sources.

\section{Introduction}

In today's world, electricity is a systemically important economic activity in all countries of the global space. In turn, energy development is the engine of all sectors of the sectoral economy, its efficiency and competitiveness, ensuring the economic security of the country, as well as influencing the well-being of the population and helping to meet its growing needs. The continuity, clarity, security and reliability of the energy system contribute to achieving the sustainable development of society as a whole.

The processes of European integration that shape the development of Ukraine's economy in the long term make it necessary to modernize the energy sector in today's conditions.

\section{Analysis of studies and publications}

\section{European energy integration}

Ukraine's electricity system is the subject of research by many domestic scientists, including: Amosha O., Stary`chenko L. and Cherevats `ky`j D. 2013; Artemchuk T. 2016; Azhnakin S. 2013; Fy'lyuk G. 2016; Khalatov A. 2016; Milyutin G. 2018; Tarasova H. 2019; Uschapovs'kyj K. 2015; Yevdokimov V. 2015; Duffield J.S. and Westphal K. 2011; Aalto P. et al. 2012.

However, dynamic changes in the electricity sector and the internationalization of the market relations require a deepening of the theoretical and methodological foundations and structural changes to ensure the needs of the economy in electric energy, as well as developing practical recommendations in the revision of the management system in the context of the unified energy system of Ukraine's functioning. 


\section{Problem statement}

The aim of this article is to develop ways of improving the efficiency of the Ukrainian energy system in the face of the European integration challenges.

To achieve the goal of the study, the following goals are identified:

$\checkmark$ to identify strategic development goals of EU countries in the field of energy;

$\checkmark$ to monitor the structure of Ukraine's unified energy system and assess its condition;

$\checkmark$ to investigate the structural trends in the changes of generated electricity to final renewable energy consumption;

$\checkmark$ to suggest ways to increase the efficiency of renewable energy sources;

$\checkmark$ to develop guidelines for improving the efficiency of the Ukrainian electric power plants in the context of the European integration choice of Ukraine.

\section{Research results}

Global trends of the intensification of economic development call for increased energy consumption, resulting in increased use of non-renewable resources and climate change. European countries are directing their energy efforts towards higher requirements and compliance for environmental protection, the reduction of industrial and domestic energy consumption, and reduction of dependence on imported energy resources, increasing the use of renewable resources in energy. Thus, in 2007, in accordance with the "Action Plan on Climate Change and Renewable Energy" the European Parliament signed the "20-20-20" plan (CEP 2019), which included measures and actions by European countries to achieve economic development targets such as:

$\checkmark$ reduce $\mathrm{CO}_{2}$ emissions by at least $20 \%$;

$\checkmark$ increase electricity production from renewable sources by at least $20 \%$ of the total, resulting in a $20 \%$ reduction in the use of non-renewable primary energy sources;

- reduce electricity consumption by at least $20 \%$ through the development and introduction of new advanced technologies and innovative materials to improve energy efficiency in economies by at least $20 \%$.

The "20-20-20" plan adopted by the European Parliament became the basis for signing in 2011 Energy Road Map - 2050 (Energy 2019), as well as, according to "Action plan on climate change and renewable energy" (EIP 2019) and for the development of a European Integrated Energy System project.

These and other documents provide a plan of action for all economic actors aimed at achieving certain energy objectives by modernizing the energy sector and building a more advanced integrated and secure energy system, as well as improving the energy conservation and energy efficiency of the EU economies. 
Ukraine joined the European Energy Community as early as 2011. This was ratified by the Law of Ukraine "On ratification of the Protocol on Ukraine's accession to the treaty establishing the energy community" (Dogovor 2010). This legislative act confirmed the directions of Ukraine's action to achieve the goals of European countries in the energy sector.

The energy sphere of our state is a unified energy system that has gone through the evolutionary path of its formation under the influence of the productive forces' location, historical, geographical and other conditions. The beginning of the energy system on the territory of Ukraine is considered to be the opening in 1886 in Poltava power, and in 191371 power plants with a total capacity 304.3 MWh were already in operation on the territory of modern Ukraine.

At that time, electricity production per inhabitant occurred to $1.5 \mathrm{kWh}$ per year. The rapid development of energy in Ukraine took place in the 1920s and 1930s, when five local power centers were united by the first, at the time, transmission line $87 \mathrm{~km}$ long with a voltage of 220 $\mathrm{kV}$, which was the beginning of the interconnection of the power system of Ukraine (DE 2018).

Ukraine's unified energy system, which is one of the most powerful energy systems in the European space, is currently being developed in accordance with the decision of the Cabinet of Ministers of Ukraine "On the approval of the Energy Strategy of Ukraine for the period up to the year 2035", "Security, Energy Efficiency, Competitiveness" (EM 2019; ESU 2017).

Ukraine's unified energy system comprises:

Firstly, power generation enterprises, which include enterprises with their own generating capacity and/or provide additional services. These enterprises include the following:

$\checkmark$ GP "NAEK Energatom", which is the operator of the nuclear power plants in Ukraine (Zaporozhye NPP, Rivne NPP, South Ukrainian NPP and Khmelnytskyi NPP);

$\checkmark$ JSC "Ukrgidroenergo", which unites 9 of the largest hydroelectric power stations and 103 hydroelectric units on the Dnieper and Dniester rivers;

$\checkmark$ five powerful power generating companies (PAO "DTEK WestEnergo", PAO "DTEK DnieperEnergo", PAO "Donbasssenergo", PAO "DTEK Vostokenero", PAO "Centrenergo"), which together number three large electric power plants and 97 power plants, of which 14 are considered to be large ones;

$\checkmark 45$ thermal power plants and various low-power block stations;

$\downarrow$ other renewable energy generating enterprises, including at the beginning of 2019: 244 solar power stations, 70 mini-hydropower stations, 22 entities using biogas for electricity generation, 17 wind farms and 10 biomass users (NCREP 2019);

$\checkmark$ secondly, enterprises carrying out the transmission of electricity through main and interstate electric power networks with a voltage from 220 to $750 \mathrm{kV}$, as well as dispatching and operational and technological management of the unified power system and the operation's synchronization of the unified power system of Ukraine with the power systems of other countries. Such enterprises include the GP "NEK "Ukrenergo", which in its structure includes the State inspectorate on energy supervision of electric and thermal energy consumption regimes and the State inspectorate on operation of power plants and networks (Ukrenergo 2019);

$\checkmark$ thirdly, enterprises engaged in the distribution of electricity (Tulchynska et al. 2018). These enterprises include 46 licensees as of the beginning of 2019, and the distribution networks 
include about 200,000 transformer substations with a voltage from 6 to $15 \mathrm{kV}$ and an extensive network of cable and air transmission lines with a length of about 1 million $\mathrm{km}$ with a voltage from 0.4 to $150 \mathrm{kV}$;

$\checkmark$ fourthly, enterprises which trade in electricity. In this aspect, significant changes have taken place in the unified energy system with the adoption in 2017 of the Law of Ukraine "On the market of electrical energy" (CEP 2019), as this legislative act has changed the operating model of the electricity market, that allowed to buy electricity not from one wholesaler, which was performed by GP "Energorynok", but through the system of concluding long-term contracts, the Day-AheadMarket and the domestic daily market.

Thus, the unified energy system of Ukraine is represented by a wide range of electric power enterprises, primarily generating, transmitting and distributing electricity from both traditional and renewable sources as well as trade. It should be noted that the changes that have taken place in the legislation of Ukraine are an important step towards improving the efficiency of both the energy system and the economy as a whole, since they have allowed the transformation of the operating model of the energy market from the monopoly model to the wholesale competition model. This model increases responsibility for the uninterrupted and high-quality supply of electricity under signed agreements; it also creates competition at the level of generators and suppliers and reduces the consumer's dependence on the electricity provider.

However, there is no particular model usually, but other models of the working electricity market. In this case, the model, which has been in operation for several years, has the characteristics of a bilateral contract model and a balancing market, and provides for agreements between the power generating enterprises and the consumers or suppliers of electricity.

At the same time, the sale takes place through the exchange. Of course, there is no ideal model for the operation of the electricity market, but the changes that have taken place have the potential to increase the attraction of investment resources into the interconnected energy system and increase its efficiency.

There have been significant changes in the structure and volume of electricity consumption in the domestic economy during the transformational period (see Table 1 and Fig. 1).

TABLE 1. The volume of electricity supply in 1990-2018 [TWh]

TABELA 1. Wielkość dostaw energii elektrycznej w latach 1990-2018 [TWh]

\begin{tabular}{|l|r|r|r|r|r|r|r|r|r|r|r|}
\hline \multirow{2}{*}{ Varieties of generations } & \multicolumn{10}{|c|}{ Years } \\
\cline { 2 - 13 } & 1990 & 2000 & 2010 & 2011 & 2012 & 2013 & 2014 & 2015 & 2016 & 2017 & 2018 \\
\hline Total & 298.5 & 171.4 & 188.1 & 194.9 & 198.9 & 194.4 & 182.8 & 163.7 & 147.7 & 144.8 & 118.3 \\
\hline Thermal power plants & 211.6 & 82.6 & 86.5 & 93.6 & 97.1 & 95.5 & 83.5 & 67.5 & 61.2 & 51.7 & 54.6 \\
\hline Nuclear power plants & 76.2 & 76.3 & 89.2 & 90.2 & 90.1 & 83.2 & 88.4 & 87.6 & 75.9 & 80.2 & 79.3 \\
\hline Wind, solar power plants & - & 0.0 & 0.1 & 0.1 & 0.6 & 1.2 & 1.6 & 1.6 & 0.9 & 2.3 & 2.3 \\
\hline $\begin{array}{l}\text { Hydroelectric power } \\
\text { plants }\end{array}$ & 10.7 & 11.5 & 13.2 & 10.9 & 11.0 & 14.5 & 9.3 & 7.0 & 9.0 & 10.3 & 11.8 \\
\hline $\begin{array}{l}\text { Other power generating } \\
\text { installations }\end{array}$ & - & - & - & - & - & - & - & - & 0.1 & 0.1 & 0.1 \\
\hline
\end{tabular}

Source: compiled on the basis of SSSU 2019 and SYU 2019. 


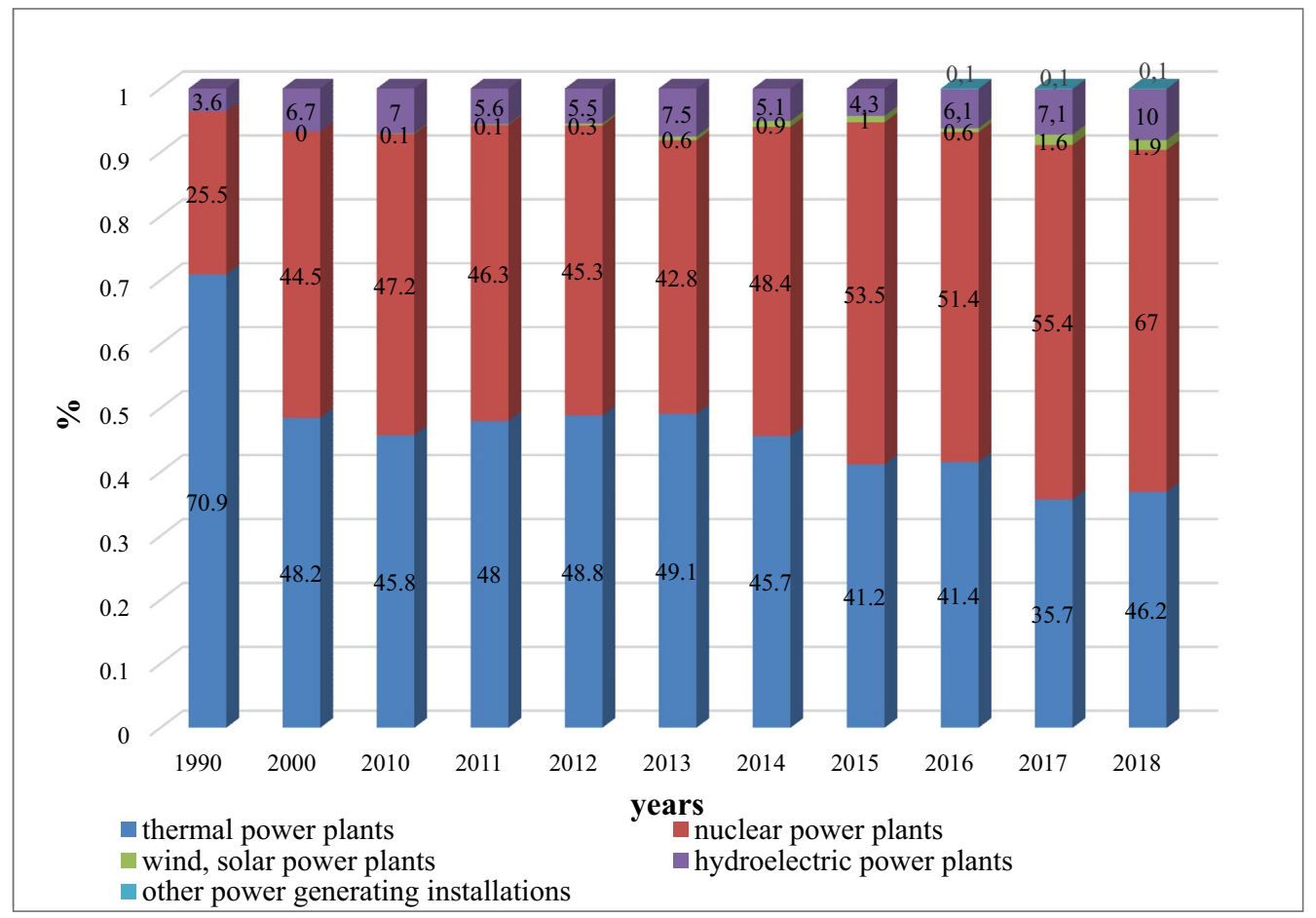

Fig. 1. Percentage of electricity output by generating enterprises of the integrated energy system of Ukraine for $1990-2018[\%]$

Source: compiled on the basis of SSSU 2019 and SYU 2019

Rys. 1. Struktura paliwowa produkcji energii elektrycznej w przedsiębiorstwach wytwórczych zintegrowanego systemu energetycznego Ukrainy w latach 1990-2018 [\%]

The data presented in Table 1 shows that there is a tendency to reduce the supply of electricity by generating enterprises in general. Thus, the reduction between 1990 and 2000 was 127.1 TWh, and from 2010 to $2018-70.1 \mathrm{TWh}$.

The largest reduction in electricity is observed in thermal power plants. If we compare 1990 and 2018, the reduction reached $157 \mathrm{TWh}$, which is almost 4 times. There is also a tendency to increase the amount of electricity generated by wind and solar power plants.

The ratio of electricity output from different generating plants illustrates the significant decrease in the proportion of production by thermal power plants from $70.9 \%$ in 1990 . Up to $46.2 \%$ in 2018 , that is a reduction of 1.5 times the total amount of electricity released to the network. The ratio of electricity supply by different generating enterprises illustrates a significant decrease in the share of production by thermal power plants from $70.9 \%$ in 1990 to $46.2 \%$ in 2018 , which is a reduction of 1.5 times the total electricity supply released to the network. The main reason for this reduction is the increase in the price of raw materials, which leads to a reduction in the efficiency of thermal power stations. 
Recently, more than half of the total volume of the electricity supply (in 2018 it is $67.0 \%$, which corresponded to $79.3 \mathrm{TWh}$ ) is carried out by nuclear power plants. In 2013, the supply of electricity by wind and solar power plants began, which in 2013 amounted to only $0.6 \%$ of the total, and in $2018-1.9 \%$. For the supply of electricity to the grid from generating enterprises operating on the use of renewable energy sources, such as wind, solar energy, the use of biomass in 2018 was $2.0 \%$, and the supply of electricity by hydropower plants was $10.0 \%$. The branching of electricity grids is important for any energy system, which allows delivering the generated electricity to consumers, because electricity is not stored and its production volumes must correspond to consumption.

Data on the availability of main and interstate power grids is presented in Table 2.

TABLE 2. Main and interstate power grids of NEC Ukrenergo, 2016-2018

TABELA 2. Główne i międzypaństwowe sieci elektroenergetyczne NEC Ukrenergo, 2016-2018

\begin{tabular}{|c|c|c|c|c|c|c|c|c|}
\hline \multirow{3}{*}{$\begin{array}{c}\text { Voltage } \\
\text { class }\end{array}$} & \multicolumn{3}{|c|}{ Power lines on the route, $[\mathrm{km}]$} & \multicolumn{3}{|c|}{$\begin{array}{l}\text { Power lines in chains, } \\
\qquad[\mathrm{km}]\end{array}$} & $\begin{array}{l}\text { Number of power } \\
\text { substations, units }\end{array}$ & $\begin{array}{c}\text { Power of } \\
\text { substations, } \\
\text { [MW] }\end{array}$ \\
\hline & \multicolumn{3}{|c|}{ Years } & \multicolumn{3}{|c|}{ Years } & \multicolumn{2}{|c|}{ Years } \\
\hline & 2016 & 2017 & 2018 & 2016 & 2017 & 2018 & 2016-2018 & 2016-2018 \\
\hline $35 \mathrm{~kW}$ & 115.2 & 112.4 & 112.4 & 116.8 & 114.0 & 114.0 & - & - \\
\hline $110 \mathrm{~kW}$ & 453.8 & 448.7 & 448.7 & 559.9 & 549.7 & 549.7 & 4 & 286.0 \\
\hline $220 \mathrm{~kW}$ & $3,019.3$ & $3,019.3$ & $3,019.3$ & $3,975.9$ & $3,975.9$ & $3,975.9$ & 33 & $9,394.2$ \\
\hline $330 \mathrm{~kW}$ & $1,2862.4$ & $12,862.3$ & $12,972.3$ & $13,423.7$ & $13,423.6$ & $13,536.7$ & 88 & $48,972.9$ \\
\hline $400 \mathrm{~kW}$ & 338.9 & 338.9 & 338.9 & 338.9 & 338.9 & 338.9 & 2 & 1609.0 \\
\hline $500 \mathrm{~kW}$ & 374.7 & 374.7 & 374.7 & 374.7 & 374.7 & 374.7 & 2 & $1,753.0$ \\
\hline $750 \mathrm{~kW}$ & $4,120.5$ & $4,120.5$ & $4,595.1$ & $4,120.5$ & $4,120.5$ & $4,595.1$ & 8 & $16,738.0$ \\
\hline $800 \mathrm{~kW}$ & 98.5 & 98.5 & 98.5 & 98.5 & 98.5 & 98.5 & - & - \\
\hline Total & $21,383.7$ & $21,375.7$ & $21,960.2$ & $23,009.3$ & $22,996.2$ & $23,583.8$ & $137 *$ & $78,753.1$ \\
\hline
\end{tabular}

* 17 substations out of 137 substations are located on the territory temporarily not under the control of the Government of Ukraine and 17 substations on the territory of the temporarily occupied Autonomous Republic of Crimea.

Source: based on NEK Ukrenergo 2020.

The transmission of electric power on main and interstate power grids of different voltages is carried out by GP "NEK Ukrenergo". According to the above data for three years, as the dynamics of changes is insignificant, 37 power substations are currently located in temporarily uncontrolled Ukraine and the occupied territories. On the positive side, the length of $750 \mathrm{~kW}$ lines increased by $474.6 \mathrm{~km}$ and the voltage $330 \mathrm{~kW}$ by $109.9 \mathrm{~km}$. This is a very important factor for the implementation of Ukraine's cooperation in the field of energy, since the domestic interconnected energy system operates in parallel with other energy systems of neighboring countries. Under the conditions of European integration processes and the development of the community in the energy sphere, an important factor is the functioning of the so-called "islands of the Bursh- 
tyn power plant", which unites the Burshtyn TPP, Terebil-Riksk HPP and Kalush TPP. The island of the Burshtyn power plant works in synchronization with the European Network of Transmission System Operators for Electricity (ENTSO-E). ENTSO-E is a conglomerate of regional electricity markets, which includes both regulated electricity supply and day-ahead electricity sales through energy exchanges. The volume of electricity exports and imports of the united power system of Ukraine is shown in Table 3.

TABLE 3. Volumes of exports and imports of electricity of the united energy system of Ukraine for 2014-2018 [GWh]

TABELA 3. Wolumeny eksportu i importu energii elektrycznej zintegrowanego systemu energetycznego Ukrainy w latach 2014-2018 [GWh]

\begin{tabular}{|c|c|c|c|c|c|}
\hline \multirow{2}{*}{ Countries } & \multicolumn{5}{|c|}{ Years } \\
\cline { 2 - 6 } & 2014 & 2015 & 2016 & 2017 & 2018 \\
\hline Export & \multicolumn{5}{|c|}{} \\
\hline Hungary & $4,145.112$ & $3,531.026$ & $3,055.630$ & $2,815.582$ & $3,594.408$ \\
\hline Slovakia & 90.279 & 21.908 & 0.128 & 162.028 & 167.660 \\
\hline Romania & 0.0 & 0.0 & 0.0 & 894.755 & 37.675 \\
\hline Poland & - & 66.495 & 957.400 & $1,133.901$ & $1,410.152$ \\
\hline Moldova & 685.780 & 17.599 & 3.702 & 0.0 & 955.779 \\
\hline Belarus & $2,400.948$ & 0.787 & 0.0 & 0.0 & 0.0 \\
\hline Imports & 177.993 & $2,295.931$ & 75.652 & 46.959 & 29.490 \\
\hline Russia & - & 0.0 & 1.207 & 1.083 & 1.188 \\
\hline Belarus & $8,052.829$ & $3,640.099$ & $4,016.860$ & $5,166.348$ & $6,165.674$ \\
\hline Total: & 177.993 & $2,295.931$ & 76.859 & 48.043 & 30.678 \\
\hline export & \multicolumn{7}{|l|}{} \\
\hline imports &
\end{tabular}

Source: compiled by the author based on Ukrenergo 2019.

The data listed in Table 3 shows significant changes in the structure of electricity imports and exports of Ukraine. Thus, in terms of imports, in 2018 the import of electricity from the Russian Federation decreased almost 78 times compared to 2015. Regarding exports, Ukraine has recently stopped exporting electricity to Belarus, but there has been an increase in electricity exports to Poland and Slovakia. In 2018, electricity exports to Poland amounted to 1,410.152 million $\mathrm{kWh}$.

Through the island of Burshtyn power plant, the united energy system of Ukraine is synchronized with ENTSO-E. The value of Ukraine's electricity export capacity to Hungary, Slovakia and Romania is up to $650 \mathrm{MWh}$, to Poland - up to $235 \mathrm{MWh}$ (DPUUESU 2018).

100 
The liberalization of the electricity market of Ukraine due to the change in the operating model of the electricity market contributes to attracting investment resources aimed at expanding the possibilities of importing electricity generated in Ukraine into the ENTSO-E system. Investment projects aim at increasing the length and extension of power lines of various capacities.

Also, one of the investment projects in this direction is the "Power Bridge of Ukraine - European Union" project, which envisages attraction of investment resources for the completion and launch of block 3 of the Khmelnytskyi nuclear power plant, which is $75 \%$ ready (and then unit 4 , which is ready to be $25 \%$ ), and the introduction of two $750 \mathrm{~kW}$ power lines by connecting them to the European ENTSO-E network via the connection to Rzeszów on the territory of Poland and Albertis on the territory of Hungary (Protokol 2019).

In August 2019, a commission meeting was held to identify a private partner in the "Energy bridge of Ukraine - European Union" project, as a result of which the Irish company became a partner of the Ministry of Energy and Environmental Protection of Ukraine "Ukraine power bridge company limited", facility - lines of electrical transmission belonging to NEK "Ukrenergo" and facilities belonging to GP NAEK "Energoatom" and referring to the Khmelnytskyi nuclear plant. The project is designed for 25 years and involves investing EUR 47.7 million in the grid, EUR 108.6 million - in electricity generation and EUR 87.2 million - in improving the efficiency of electricity production of Khmelnitsky nuclear power plant through modernization equipment.

Institutional changes that have taken place in Ukraine in the energy sector, as well as European integration processes have influenced the formation of tasks in the energy sector, which are in line with global priorities for sustainable development and European objectives for energy efficiency and energy conservation. Namely, Ukraine faces the task of:

$\checkmark$ ensuring the modernization of the energy sector;

$\checkmark$ protecting the interests of the stakeholders in the energy market, optimizing the country's energy mix and increasing the country's energy independence;

$\checkmark$ reducing energy losses and improving the energy efficiency of the united energy system;

$\downarrow$ increasing the generation of electricity from renewable sources and increase the efficiency of their use;

$\downarrow$ ensuring transparency of the energy market and taking timely and effective management decisions to reduce the electrical capacity of the gross national product, which is currently ranked eighth in the world ranking.

One of the major challenges facing European countries and the world economy as a whole is the promotion of renewable energy. These aspirations are proclaimed in the documents adopted by the European Parliament: "The EU Energy Strategy until 2020" (Energy 2019), "Action plan to combat climate change and the use of renewable energy", "20-20-20" pln (CEP 2019) etc.

The spread of renewable energy sources enhances the energy security and independence of countries by reducing imports of primary energy and electricity in general, and has positive environmental effects. It should be noted that the share of electricity generated from renewable energy sources is highly uneven across Europe (Table 4). 
TABLE 4. Share of energy from renewable sources in European countries

[\% of gross final energy consumption*]

TABELA 4. Udział energii ze źródeł odnawialnych w krajach europejskich

[\% końcowego zużycia energii brutto*]

\begin{tabular}{|c|c|c|c|c|c|c|}
\hline Countries & 2004 & 2014 & 2015 & 2016 & 2017 & The goal by 2020 \\
\hline EU & 8.5 & 16.2 & 16.7 & 17.0 & 17.5 & 20 \\
\hline Austria & 22.7 & 33.2 & 32.8 & 33.0 & 32.6 & 34 \\
\hline Albania & 29.6 & 31.5 & 34.4 & 37.1 & 34.6 & 38 \\
\hline Belgium & 1.9 & 8.0 & 7.9 & 8.6 & 9.1 & 13 \\
\hline Bulgaria & 9.4 & 18.0 & 18.2 & 18.8 & 18.7 & 16 \\
\hline Greece & 6.9 & 15.4 & 15.4 & 15.1 & 16.3 & 18 \\
\hline Denmark & 14.9 & 29.7 & 31.4 & 32.6 & 35.8 & 30 \\
\hline Estonia & 18.4 & 26.2 & 28.4 & 28.6 & 29.2 & 25 \\
\hline Ireland & 2.4 & 8.7 & 9.1 & 9.3 & 10.7 & 16 \\
\hline Spain & 8.3 & 16.1 & 16.2 & 17.4 & 17.5 & 20 \\
\hline Italy & 6.3 & 17.1 & 17.5 & 17.4 & 18.3 & 17 \\
\hline Cyprus & 3.1 & 8.9 & 9.4 & 9.3 & 9.9 & 13 \\
\hline Latvia & 32.8 & 38.6 & 37.5 & 37.1 & 39.0 & 40 \\
\hline Lithuania & 17.2 & 23.6 & 25.8 & 25.6 & 25.8 & 23 \\
\hline Luxembourg & 0.9 & 4.5 & 5.0 & 5.4 & 6.4 & 11 \\
\hline Macedonia & 15.7 & 19.6 & 19.5 & 18.0 & 19.7 & 28 \\
\hline Malta & 0.1 & 4.7 & 5.1 & 6.2 & 7.2 & 10 \\
\hline Netherlands & 2.0 & 5.5 & 5.7 & 5.9 & 6.6 & 14 \\
\hline Germany & 6.2 & 14.4 & 14.9 & 14.9 & 15.5 & 18 \\
\hline Poland & 6.9 & 11.5 & 11.7 & 11.3 & 10.9 & 15 \\
\hline Portugal & 19.2 & 27.0 & 28.0 & 28.4 & 28.1 & 31 \\
\hline Romania & 16.2 & 24.8 & 24.8 & 25.0 & 24.5 & 24 \\
\hline Serbia & 12.7 & 22.9 & 21.9 & 21.0 & 20.6 & 27 \\
\hline Slovenia & 16.1 & 21.5 & 21.9 & 21.3 & 21.5 & 25 \\
\hline Slovakia & 6.4 & 11.7 & 12.9 & 12.0 & 11.5 & 14 \\
\hline The United Kingdom & 1.1 & 6.5 & 8.4 & 9.2 & 10.2 & 15 \\
\hline Turkey & 16.2 & 13.6 & 13.6 & 13.7 & 13.2 & - \\
\hline Hungary & 4.4 & 14.6 & 14.4 & 14.3 & 13.3 & 13 \\
\hline Finland & 29.2 & 38.8 & 39.3 & 39.0 & 41.0 & 38 \\
\hline France & 9.5 & 14.8 & 15.2 & 15.9 & 16.3 & 23 \\
\hline Croatia & 23.5 & 27.8 & 29.0 & 28.3 & 27.3 & 20 \\
\hline Czech Republic & 6.9 & 15.0 & 15.0 & 14.9 & 14.8 & 13 \\
\hline Montenegro & - & 44.1 & 43.1 & 41.5 & 40.0 & 33 \\
\hline Sweden & 38.7 & 52.4 & 53.6 & 53.8 & 54.5 & 49 \\
\hline
\end{tabular}

* Gross final energy consumption is defined in Directive 2009/28/EC on renewable energy sources as energy commodities delivered for energy purposes to final consumers, including the consumption of electricity and heat by the energy branch for electricity and heat production, and including losses of electricity and heat in distribution and transmission.

Source: compiled from data ERE 2019.

102 
The data provided make it possible to determine that the potential for renewable energies varies considerably from country to country.

There are countries that have already achieved predefined targets for the share of electricity consumption derived from renewable energy sources. These countries are: Bulgaria, Denmark, Estonia, Italy, Lithuania, Romania, Hungary, Croatia, Czech Republic, Montenegro and Sweden.

The countries with the largest share of renewable energy consumption as of 2017 are: Sweden $54.5 \%$, Finland $-41.0 \%$, Montenegro $-40.0 \%$, Latvia $-39.0 \%$, Denmark $-35.8 \%$, Albania $-34.6 \%$ and Austria $-32.6 \%$. However, there are countries where the proportion is much lower. These include: Luxembourg $-6.4 \%$, the Netherlands $-6.6 \%$, Malta $-7.2 \%$, Belgium 9.1\%, Cyprus $-9.9 \%$, Great Britain $-10.2 \%$, Ireland $-10.7 \%$ and Poland $-10.9 \%$.

Overall, for the EU countries in 2017, the share of energy consumption from renewable sources is $17.5 \%$. In 2004 , it was 2 times lower, at $8.5 \%$. Regarding the amount of electricity generation from renewable energy sources in our country, in accordance with the "Energy strategy of Ukraine" in 2030, achieving it in the amount of $10 \%$ of the total size is planned. However, in 2018 this parameter was only $1.7 \%$.

It should be noted that the achievement of high rates of renewable energy use is due to the long-term policy of European countries in accordance with the paradigm of sustainable development, aimed at developing green energy and attracting investment resources in this area. A factor that is still hampering the spread of renewable energy sources is that the cost of such electricity is still higher than the cost of electricity generated by the use of traditional resources.

During the period 2014-2017, EU countries invested EUR 290.68 billion in the development of energy generating electricity from renewable sources. The countries that have attracted the largest amount of investment in this area include: Spain, Germany, Italy, France and the United Kingdom. Among the countries of the world, the leaders in terms of investment in the development of electricity from renewable sources are the United States, where the volume of investment reaches - USD 214.96 billion. It is also necessary to note China USD 197.49 billion, Brazil - USD 52.31 billion, India - USD 39.72 billion and Canada USD 23.88 billion.

If we consider Ukraine, investment of EUR 3.3 billion was attracted in 2014-2017 for renewable energy. According to the strategic plans for the development of the electric power industry in Ukraine, attracting investments in the amount of EUR 30 billion by 2035 was planned (VNE 2018). Undoubtedly, the increase in investment will contribute to the development of the use of renewable energy sources for electricity generation.

The use of renewable energy sources contributes to improving the country's energy security and greening economic development. Of course, the use of these sources undoubtedly has positive aspects. However, like any other process, the use of renewable sources also has certain disadvantages.

The disadvantages of using solar energy are the location of solar installations on a large area of land in addition to the low intensity of solar radiation, which depends on natural conditions. And another disadvantage that will arise in the future is the disposal of solar panels containing harmful substances. 
The use of wind energy also has natural limitations due to unregulated wind flow, as well as the production of high frequency noise and vibration by wind farms. Their operation creates interference for radio frequencies, vibration, and requires the use of a large area of land for their placement. The negative environmental impacts are related to possible damage to birds. Hydropower plants require flooding of a certain area of land, which, in turn, negatively affects and disturbs the ecosystem balance of territories, as this can lead to changes in the microclimate and the destruction of the habitat of certain species of living organisms. The construction of hydroelectric power plants also requires significant investments and high operating costs. The most environmentally friendly is bioenergy, which has no waste during generation. However, environmentalists emphasize that the use of livestock products can lead to a loss of soil quality due to reduced organic fertilizers.

In our opinion, carrying out environmental measures is necessary in order to eliminate the negative effects of the using renewable energy. It is, of course, impossible to change the intensity of solar energy or the direction of wind currents. However, to reducing the use of land resources, we propose to place solar panels on ponds, roofs, unproductive lands.

Regarding the utilization of used solar panels, it should be noted that due to the use of more advanced technologies their service life increases and reaches more than 50 years and their processing and utilization becomes less expensive, and also significantly reduces the cost of solar panels due to the less expensive production of photovoltaic cells.

As for wind power plants, one of the ways to level their environmental impact may be their location in the waters, mountains, which is also facilitated by stronger wind currents. Despite the high operating costs of hydroelectric power plants, they have an indisputable positive in relation to the constant restoration of natural energy reserves. Their location on small rivers, as well as where the greatest natural difference in water level is more optimal.

Despite the shortcomings of defining electricity generation from renewable energy sources, it should be noted that their use contributes to the greening of the economy in general, and the development of innovative technologies in this area helps reduce the cost of power generation.

As world experience shows, improving the efficiency of energy systems requires attracting investment resources into the energy sector.

The use of the public-private partnership mechanism may be a way of increasing the attraction of investment resources to the unified energy system of Ukraine. Changes in the operation of the electricity market model are contributing positively to this. The process of attracting private capital to the energy sector has already started (the article cited the example of nuclear energy).

The legal framework for public-private partnerships in Ukraine is formed and allows the use of this mechanism to attract investment. In Ukraine, public-private partnerships are widely used in water supply, as well as in the production, transportation and supply of heat. In the energy sector, 187 investment projects have been signed since the beginning of 2020, but only 52 projects are being implemented. One of the biggest projects, as already mentioned, is the project within the framework of "Energy Bridge Ukraine - European Union".

It should also be noted that, despite changes in the direction of liberalization of the energy market by changing the model of its functioning, there are aspects that hinder the development 
of public-private partnership, including, in particular, political instability, bureaucracy, non-transparency and corruption.

To intensify the mechanism of attracting public-private partnership is the following are necessary:

$\downarrow$ directing efforts for the further implementation of European legislation and experience in energy development, including investment in innovation and technological developments in this area;

$\downarrow$ compliance with the requirements of international law regarding lawsuits of investors and ensuring the protection of the rights of participants in investment projects;

$\checkmark$ increasing the level of management of authorities at various levels to work with private investors, which requires increasing the level of sociability and competence of employees;

$\checkmark$ ensuring information support and transparency in investment procedures for attracting investment resources with the participation of public-private partners, leveling bureaucratic barriers during the conciliation procedures;

$\checkmark$ raising the level of methodological bases for the establishment, passing and approval of projects with the participation of public-private partnership, taking into account the European experience of signing agreements in the field of electricity;

$\checkmark$ promoting the reduction of possible risks due to the emergence of debt obligations to a private partner, the introduction of tax and customs benefits for a private partner when involved in investment projects in the energy sector.

The outlined directions will contribute to the achievement of the goals of sustainable development through the modernization of the unified energy system of Ukraine due to the intensification of investment in this sphere through public-private partnerships.

\section{Conclusions}

Thus, the identification of EU countries' strategic development goals in the energy sector has proved that they are relevant and unconditional for implementation in Ukraine in the energy sector. Monitoring the unified energy system of Ukraine has shown that Ukraine has powerful energy-generating nuclear, hydro, heat and power plants, energy-generating renewable energy companies, as well as companies that transmit and trade electricity. At the same time, the amount of electricity produced in Ukraine has almost halved over the past three decades, mainly as a result of the reduction in the output of thermal power. This is primarily due to the significant increase in the cost of primary import resources. In order to increase electricity exports to European countries, it is necessary to increase the length of power lines, which has been observed in Ukraine in recent years, namely an increase of $474.6 \mathrm{~km}$ in the length of $750 \mathrm{~kW}$ and $109.9 \mathrm{~km}-330 \mathrm{~kW}$. This will increase the size of Ukraine's electricity exports to Hungary, Slovakia, Romania and Poland through the island of the Burshtyn Power Plant of the Unified Energy System of Ukraine, which is synchronized with ENTSO-E. 
Isolation of structural trends in the change of generated electricity in final consumption due to renewable energy sources of European countries showed that the growing share of electricity consumption from renewable sources provides increased energy security and energy independence of countries due to the reduced imports of primary energy and electricity and also has a positive environmental effect. This requires intensifying the attraction of investment resources in the development of renewable energy enterprises.

The study of the renewable energy's negative effects has made it possible to propose ways of eliminating them. For example, in order to reduce the use of land, it is suggested that solar panels should be placed on water bodies, roofs, low-productivity land, more optimal location of hydroelectric power plants on small rivers, and where the water level is the most natural and so on.

The management directions of efficiency's increasing at the electric power enterprises in the conditions of the European integration choice of Ukraine, consisting in the further liberalization of the power market of Ukraine and intensifying the attraction of investment resources in this area, including through public-private partnership are offered. Directions for the implementation of European experience in improving the energy efficiency of Ukraine's energy sector require further research.

\section{References}

Aalto et al. 2012 - Aalto, P., Harle, V. and Moisio, S. eds. 2012. Towards a wider European energy security society: from vulnerability and viability to sustainability. Global and regional problems: Towards Interdisciplinary study (Farnham: Ashgate).

Amosha et al. 2013 - Amosha, O.I., Stary`Chenko, L.L. and Cherevats'KY`J, D.Yu 2013. State, main problems and prospects of the coal industry of Ukraine: scientific report (Stan, osnovni problemy' i perspekty 'vy 'vugil ’noyi promy 'slovosti Ukrayiny '). NAN Ukrayiny', In-t ekonomiky` prom.-sti. Donecz`k (in Ukrainian).

ArTemchuK, T.O. 2016. Increasing the Social Productivity of Natural Power Monopoly Enterprises (Pidvyschennia suspil'noi rezul 'tatyvnosti diial'nosti pidpryiemstv pryrodnykh monopolij elektroenerhetyky). Visnyk Sums 'koho natsional'noho ahrarnoho universytetu Vol. 4, pp. 146-151 (in Ukrainian).

AzHNAKIN, S.H. 2013. Problems of energy saving and energy efficiency of activity of electric power enterprises (Problemy enerhozberezhennia ta enerhoefektyvnosti diial'nosti elektroenerhetychnykh pidpryiemstv). Ekonomichni innovatsii Vol. 55, pp. 9-22 (in Ukrainian).

CEP 2019. The climate and energy package [Online] http://ec.europa.eu/clima/policies/package/index en.ht [Accessed: 2019-12-16].

DE 2018. Present and past (Nastoyashhee y`proshloe). DonbassEnergo (DonbassЭnergo). [Online] https://fileview.fwdedn.com/?url=https\%3A\%2F\%2Fmail.ukr.net\%2Fapi\%2Fpublic\%2Ffile_view\%2Flist\%3Ftoken\%3D8JctgPjN8PINxU4DLVOaWAinZZvmeYRJLJRn1Y2EASashGI-2JgKRQT40O6ttr6pKX-MLXbpFeSxUmJKjO2Zq5O_1KKtlNw\%253AYzJPi2bxQYB3WO0r\%26r\%3D1574253116441\&default_mode=view\&lang=ru\#start=7 [Accessed: 2018-12-12].

Dogovor 2010. On ratification of the Protocol of Accession of Ukraine to the Treaty establishing the Energy Community (Pro raty 'fikaciyu Protokolu pro pry'yednannya Ukrayiny'do Dogovoru pro zasnuvannya Energety 'chnogo Spivtovary 'stva). Zakon Ukrayiny 'Vol. 2787-VI, dated 15.12.2010 (in Ukrainian). 
DPUUESU 2018. Development Plan of the United Energy System of Ukraine for 2016-2025 (Plan rozvy 'tku Ob'yednanoyi energety 'chnoyi sy 'stemy 'Ukrayiny` na 2016-2025 roky '). [Online] https://drive.google.com/file/d/0BwZR8kgLwyBtSUV0MTJ0eGtPZHM/view [Accessed: 2018-08$10]$.

Duffield, J.S. and Westphal, K. 2011. Germany and EU Energy Policy: Conflicted Champion of Integration? Toward a Common European Union Energy Policy. Palgrave Macmillan, New York; DOI: $10.1057 / 9780230119819$ 9.

EIP 2019. Energy infrastructure priorities for 2020 and beyond - A Blueprint for an integrated European energy network. [Online] http://eurlex.europa.eu/LexUriServ/LexUriServ.do?uri=CELEX:52011PC0658:EN:NOT [Accesed: 2019-12-18].

EM 2019. On the electricity market (Pro ry 'nok elektry 'chnoyi energiyi). Zakon Ukrayiny 'Vol. 2019-VIII, dated 24.09.2019.

Energy 2019. Energy 2020 A strategy for competitive, sustainable and secure energy. [Online] http://eurlex.europa.eu/LexUriServ/LexUriServ.do?uri=CELEX: 52010DC0639:EN:HTML:NOT [Accessed: 2019-12-20].

ERE 2019. Eurostat. Renewable energy in the EU. [Online] https://ec.europa.eu/eurostat/documents/2995521/9571695/8-12022019-AP-EN.pdf/b7d237c1-ccea-4adc-a0ba-45e13602b428 [Accessed: 2019-11-03].

ESU 2017. On approval of the Energy Strategy of Ukraine for the period up to 2035 "Security, energy efficiency, competitiveness" (Pro sxvalennya Energety 'chnoyi strategiyi Ukrayiny 'na period do 2035 roku "Bezpeka, energoefekty 'vnist', konkurentospromozhnist'”). Rozporyadzhennya kabinetu Ministriv Ukrayiny` Vol. 605-r of August 18, 2017 (in Ukrainian).

FY`LYUK, G. 2016. Problems of development of the Ukrainian electric power industry and ways of their solution (Problemy` rozvy 'tku ukrayins 'koyi elektroenergety 'ky 'ta shlyaxy 'yix rozv'yazannya). Ekonomika Vol. 4, No. 181, pp. 6-11.

Khalatov, A.A. 2016. Energy of Ukraine: the current state and immediate prospects (Energetika Ukraina cuchasniy stan I nayblizchi perspektivi). Bulletin of the National Academy of Sciences of Ukraine Vol. 6, pp. 53-61 (in Ukrainian).

MiLYUTIN, G.V. 2018. Analysis of forecasts for the development of electricity in Ukraine and the world (Analiz prognoziv rozvy 'tku elektroenergety 'ky` $v$ Ukrayini ta sviti). Ekonomika ta pidpry'yemny 'cztvo Vol. 40. pp. 42-60 (in Ukrainian).

NCREP 2019. Nacional'na komisiya, shho zdijsnyuye derzhavne regulyuvannya u sferi energety'ky' ta komunal ny`x poslug (NKREKP) (National Commission for State Regulation of Energy and Utilities (NCREP)) [Online] http://www.nerc.gov.ua/index.php/map_11/laws/data/filearch/Materialy_zasidan/2018/?id=39296 [Accessed: 2019-11-21].

NEK Ukrenergo 2020. Vidnovlyuval’na energety`ka: chy` ye perspekty`vy` dlya investuvannya (SE NEK Ukrenergo). [Online] https://ua.energy/about/merezhi-ukrenergo/\#1538032249011-abadd3b9-db7c3dc4-2b07 [Accessed: 2020-01-18].

Protokol 2019. Minutes of the meeting of the commission on the competition to determine the public-private partner for the implementation of public-private partnership on the project "Energy Bridge Ukraine European Union” (Protokol zasidannya komisiyi z py ‘tan ` provedennya konkursu z vy znachennya derzhavno-pry 'vatnogo partnera dlya zdijsnennya derzhavno-pry 'vatnogo partnerstva shhodo proektu “Energety 'chny j mist Ukrayina - Yevropejs `ky j Soyuz"). [Online] http://mpe.kmu.gov.ua/minugol/ doccatalog/document?id=245390058 [Accessed: 2019-06-15].

SSSU 2019. Fuel and energy resources of Ukraine. Statistical collection. State Statistics Service of Ukraine

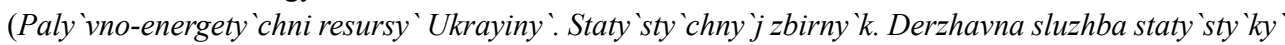
Ukrayiny '). [Online] http://www.ukrstat.gov.ua/ [Accessed: 2019-12-05]. 
SYU 2019. Statistical Yearbook of Ukraine for 2018 (Staty sty ‘chny j shhorichny`k Ukrayiny`za 2018 r.). Derzhavna sluzhba staty`sty`ky`Ukrayiny`. [Online] http://www.ukrstat.gov.ua/ [Accessed: 2019-12$11]$.

TARASOva, H.O. 2019. Formation of strategy of management of development of industrial enterprises in conditions of economic instability: theory, methodology and practice (Formuvannia stratehii upravlinnia rozvytkom promyslovykh pidpryiemstv $v$ umovakh ekonomichnoi nestabil'nosti: teoriia, metodolohiia ta praktyka). FOP Khalikov R.Kh., Kyiv (in Ukrainian).

TulchynsKa et al. 2018 - TulchynSKa, S.O., SHEVChuK, N.O. and CHORNIJ, B.P. 2018. The use of a methodological approach to assessing the attraction of investment resources in the distribution of electricity under conditions of diversification of their sources (Vy 'kory`stannya metody 'chnogo pidxodu do ocinyuvannya zaluchennya investy 'cijny 'x resursiv u pidpry yemstva rozpodilennya elektroenergiyi za umov dy 'versy 'fikaciyi yix dzherel). Naukovy j visny `k Nacional ’nogo girny `chogo universy ‘tetu Vol. 2, No. 164. pp. 130-135 (in Ukrainian).

Ukrenergo 2019. Balance of flows between the energy system of Ukraine and the energy systems of neighboring countries (Sal'do peretokiv mizh energosy 'stemoyu Ukrayiny' $i$ energosy 'stemamy sumizhny'x krayin). [Online] https://ua.energy/diyalnist/dyspetcherska-informatsiya/peretoky/\#1535440713352-591fa8d3-10dc [Accessed: 2019-12-19].

Uschapovs'KYJ, K.V. 2015. Natural Infrastructure Monopolies in the Electric Power Industry of Ukraine: Features of Functioning and Development (Pryrodni infrastrukturni monopolii v elektroenerhetytsi Ukrainy: osoblyvosti funktsionuvannia ta rozvytku). Ekonomichnyj prostir Vol. 99, pp. 68-78 (in Ukrainian).

VNE 2018. Renewable energy: whether there are prospects for investment (Vidnovlyuval 'na energety 'ka: chy ye perspekty vy` dlya investuvannya). [Online] https://mind.ua/openmind/20200969-vidnovlyuvalna-energetika-chi-e-perspektivi-dlya-investuvannya [Accessed: 2018-10-15].

YEVDOKIMOV, V.A. 2015. Improvement of approaches to the functioning of mechanisms of state regulation of development of the electric power industry (Udoskonaleniya pidhodiv do funkcionuvaniya mehanizmiv dergavnogo regulivaniya rozvitku electro energetichnoi galuzi). Actual problems of public administration Vol. 1, pp. 182-187 (in Ukrainian).

\section{System elektroenergetyczny Ukrainy - dążenie do europejskiej integracji energetycznej}

\section{Streszczenie}

W artykule sprecyzowano strategiczne cele rozwoju energetyki UE, które zmierzają do zwiększenia przestrzegania wymogów ochrony środowiska, zmniejszenia zużycia energii w sektorze produkcyjnym i usługowym, zmniejszenia zależności od importu energii oraz zwiększenia zaangażowania odnawialnych źródeł energii. Przedstawiono strukturę jednolitego systemu energetycznego Ukrainy. Analizie poddano 
ilości energii elektrycznej wyprodukowanej przez różne przedsiębiorstwa energetyczne na Ukrainie, a także istniejącą przepustowość głównych i międzypaństwowych sieci elektroenergetycznych do przesyłu energii elektrycznej. Przedstawiono wielkość eksportu i importu energii elektrycznej zunifikowanego systemu energetycznego Ukrainy oraz zbadano możliwości zwiększenia eksportu do krajów UE.

Udowodniono, że liberalizacja rynku energii elektrycznej Ukrainy w wyniku zmiany modelu funkcjonowania rynku energii elektrycznej sprzyja pozyskiwaniu środków inwestycyjnych, których celem jest zdywersyfikowanie możliwości eksportu energii elektrycznej wytworzonej na Ukrainie do systemu ENTSO-E. Badano strukturalne zmiany udziału ilości wytwarzanej w kraju energii elektrycznej w zużyciu finalnym kosztem odnawialnych źródeł energii krajów europejskich i Ukrainy. Proponowane są opcje zwiększenia efektywności odnawialnych źródeł energii. Proponuje się wykorzystanie odnawialnych źródeł energii na zasadzie niwelowania pewnych niedogodności. W warunkach wyboru integracji europejskiej Ukrainy niezbędne są działania w kierunku poprawy zarządzania przedsiębiorstwami elektroenergetycznymi, w tym przyciąganie środków inwestycyjnych poprzez wykorzystanie partnerstw publiczno-prywatnych do zwiększenia efektywności systemu energetycznego Ukrainy.

SŁOWA KLUCzOWE: efektywność energetyczna, wytwarzanie, energia elektryczna, procesy integracji europejskiej; odnawialne źródła energii 
